\title{
Reflexões pedagógicas a partir da partilha de experiências entre um docente de Ensino Religioso e um pesquisador desta politica educacional
}

\author{
Pedagogical reflections from the sharing of experiences \\ between a teacher of Religious Education and a researcher of \\ this educational policy
}

Irineu Juarez Schutz ${ }^{1}$

Evaldo Luis Pauly ${ }^{2}$

\section{Resumo}

O artigo realiza uma reflexão dialógica entre, de um lado, a experiência de um professor de Ensino Religioso e, de outro, a de um pesquisador sobre a política educacional. A redação conjunta do artigo visa à qualificação epistemológica do Ensino Religioso enquanto disciplina curricular do Ensino Fundamental e como área do conhecimento. $\mathrm{O}$ artigo se divide em duas partes. Na primeira, apresentam-se relatos do professor de ensino religioso que sustentam a reflexão político-pedagógica sobre a experiência letiva com esta disciplina. Na segunda parte, o artigo, tem o objetivo de discutir sobre a experiência de ser professor de Ensino Religioso, no contexto da simultânea desvalorização desta disciplina como área do conhecimento e como área de formação docente específica. A ausência de normas nacionais para a licenciatura em Ensino Religioso, inviabiliza a formação profissional do docente desta disciplina em nível superior com licenciatura e habilitação unificadas nacionalmente.

\footnotetext{
${ }^{1}$ Professor de Ensino Religioso do Colégio La Salle Santo Antônio - Porto Alegre/RS - Brasil. Pós Graduação em Ensino Religioso e Especialização em Coordenação Pedagógica: Gestão e Supervisão Escolar. Graduação em Pedagogia pela Universidade Federal do Rio Grande do Sul (2007); e Graduação em Filosofia pela Faculdade de Filosofia Nossa Senhora da Conceição (2001). Atualmente professor de Ensino Religioso no Ensino Fundamental II e Ensino Médio do Colégio La Salle Santo Antônio. Lattes: http://lattes.cnpq.br/6595029437472018

${ }^{2}$ Doutor em Educação pela Universidade Federal do Rio Grande do Sul (2000). Bacharel (1985) e Mestre em Teologia (1993) pela Faculdades EST de São Leopoldo/RS. Coordena o Grupo de Pesquisa "Temáticas Lassalistas" vinculado ao Programa de Pós-Graduação em Educação da Universidade La Salle de Canoas/RS. Publicou artigos sobre Lutero e a Educação, Ensino Religioso, Pedagogia de São João Batista de La Salle, entre outros temas. Lattes: http://lattes.cnpq.br/7187415721002122
} 
Religare, ISSN: 19826605, v.15, n.1, agosto de 2018, p.127-155.

Palavras-chave: Ensino Religioso; práticas letivas; formação do professor de Ensino Religioso; laicidade.

\section{Abstract}

The article presents a dialogical reflection between, from one side, the experience of a teacher of Religious Education and, the thoughts of an educational policy researcher, on the other. The joint writing of the article aims at the epistemological qualification of Religious Education as a curricular discipline of Elementary School and as an area of knowledge. The article is divided into two parts. In the first one, there are reports of the teacher of religious education that supports the political-pedagogical reflection on the teaching experience with this course. In the second part, the article aims to discuss the experience of being a teacher of Religious Education, in the context of the simultaneous devaluation of this discipline as an area of knowledge and as an area of specific teacher training. The absence of national norms for the degree in Religious Education impedes the professional formation of the teacher of this discipline at a higher level with a degree and qualification unified nationally.

Keywords: religious education, didatical practices, teacher training in religious education, secularity

\section{Introdução}

O artigo apresenta uma reflexão dialógica entre um professor de Ensino Religioso com 16 anos de experiência letiva e um pesquisador que analisa a contribuição histórica de Lutero e La Salle para a legitimação cultural do projeto político-pedagógico de universalizar a Educação Básica. O foco desta reflexão nascida do diálogo entre a prática e a pesquisa é o artigo $2^{\circ}$ da Lei de Diretrizes e Bases da educação nacional. LDB: “A educação, dever da família e do Estado, inspirada nos princípios de liberdade e nos ideais de solidariedade humana, tem por finalidade o pleno desenvolvimento do educando, seu preparo para o exercício da cidadania e sua qualificação para o trabalho" (BRASIL, 1996).

A reflexão sobre a prática letiva do docente do Ensino Religioso pode e deve ser confrontada com a determinação da LDB acerca das finalidades da educação brasileira. Por óbvio, surgem questões teóricas e práticas a partir da 
Religare, ISSN: 19826605, v.15, n.1, agosto de 2018, p.127-155.

necessidade de qualquer docente comprometido com essa disciplina, enfrentálas com seus alunos na sala de aula, fundamentando-se no conhecimento científico de sua disciplina e na sua habilitação profissional para o Magistério. No caso específico deste artigo, tratamos o Ensino Religioso como área do conhecimento. $\mathrm{O}$ artigo não discute a religião como parte integrante e integradora do direito de o indivíduo e os grupos sociais exercerem com responsabilidade sua liberdade de consciência, de crença religiosa, de livre filiação e livre permanência, como está assegurado pela Constituição Federal de 1988:

Art. 5o Todos são iguais perante a lei, sem distinção de qualquer natureza, garantindo-se aos brasileiros e aos estrangeiros residentes no País a inviolabilidade do direito à vida, à liberdade, à igualdade, à segurança e à propriedade, nos termos seguintes:

$[\ldots]$

VI - é inviolável a liberdade de consciência e de crença, sendo assegurado o livre exercício dos cultos religiosos e garantida, na forma da lei, a proteção aos locais de culto e a suas liturgias; (BRASIL, 1988)

A lei ordinária para efetivar a proteção aos cultos e às liturgias ainda não foi objeto de deliberação pelo Congresso Nacional. Através do diálogo entre a experiência da docência no Ensino Religioso e a experiência da pesquisa sobre essa disciplina escolar, o artigo desenvolverá uma reflexão pedagógica capaz de levantar alguns elementos teórico-práticos necessários para enfrentar três questões específicas do Ensino Religioso no contexto da LDB: 1) Como o Ensino Religioso contribui para a distinção republicana entre o dever da família e o dever do estado com a educação, especificamente, no campo do conhecimento religioso? 2) Quais seriam as implicações didáticas da disciplina Ensino Religioso que se inspiram na liberdade e na solidariedade? 3) Como o Ensino Religioso pode e deve contribuir para a plenitude da personalidade, para o exercício democrático e para o trabalho? 
Religare, ISSN: 19826605, v.15, n.1, agosto de 2018, p.127-155.

\section{Relato de partilha: uma reflexão politico-pedagógica sobre a experiência docente no Ensino Religioso}

A necessidade de buscar repostas para as três questões apresentadas no parágrafo anterior são mais do que evidentes, considerando que o Ensino Religioso é uma disciplina muito peculiar do currículo da educação obrigatória brasileira:

Em relação à configuração do ensino religioso enquanto disciplina escolar, não há orientações do Ministério da Educação (MEC) acerca dos conteúdos a serem ministrados, bem como não há diretrizes exaradas pelo Conselho Nacional de Educação (CNE) que orientem a formação docente e os critérios de admissão de professores para lecioná-la. (AMARAL, et. al., 2017, p. 272)

Exatamente por causa destas ausências no campo das normativas educacionais, nos parece necessário e conveniente aprofundar a pesquisa sobre o Ensino Religioso enquanto disciplina curricular do Ensino Fundamental e também enquanto área do conhecimento que, desde 1996, vem sendo experimentada pelos docentes de Ensino Religioso nas salas de aulas do país. Diante deste universo das aulas de Ensino Religioso que se concretiza diariamente nas diversas instituições de ensino, tanto públicas quanto privadas, queremos relatar experiências letivas de um professor em sua sala de aula, demonstrando sua realidade prática e que, muitas vezes, fica distante da teorização que se concentra em torno das discussões sobre os conteúdos programáticos e a formação do professor de Ensino Religioso.

O artigo inicia o diálogo, compartilhando a experiência de um professor que atua no Ensino Religioso principalmente em escolas confessionais, mas também no Ensino Público em duas partes. Nesta primeira partilha descreveremos e refletiremos sobre os conhecimentos e aprendizagens que os alunos adquirem a partir das aulas de Ensino Religioso, nos diversos níveis de ensino, desde as séries iniciais e finais do ensino fundamental e no ensino médio 
Religare, ISSN: 19826605, v.15, n.1, agosto de 2018, p.127-155.

no que se refere ao acolhimento dos alunos desta área de conhecimento e sua valorização enquanto disciplina. Na segunda parte, discutiremos a experiência de ser professor de Ensino Religioso e sua (des)valorização no currículo escolar; e as reações e comportamentos das famílias provocados pela experiência letiva desenvolvida pela disciplina "Ensino Religioso" na vida de seus filhos. Há muitos exemplos dessas reações, mas destacamos a de um casal que solicitou explicações ao professor sobre as razões pelas quais seu filho tirou uma "nota ruim" no Ensino Religioso, considerando que sua criança frequentava regularmente a missa. Outra reação foi o agradecimento de um pai de aluno pelo fato de seu filho ter sido estimulado pelo docente a apresentar a sua religião de matriz afro-brasileira na aula de Ensino Religioso. O pai percebeu pelo relato posterior do seu filho que sua religião, a Umbanda, foi tratada de modo respeitoso pela turma, pelo docente e pela escola. O pai do referido aluno exercia a liderança religiosa como pai de santo e estava agradecido porque, como relatou, ele e seu filho já haviam sofrido discriminações por causa de sua religiosidade.

Para os alunos das séries iniciais do Ensino Fundamental, parece que o Ensino Religioso torna-se uma disciplina muito gratificante, talvez porque seja oferecida em apenas um período semanal, talvez porque seja lecionada por um professor especializado em Ensino Religioso. Fato é que os alunos ficam ansiosamente aguardando o momento da aula de Ensino Religioso. Alguns comentam "É uma das melhores aulas, falamos da vida, aprendemos coisas diferentes e passa muito rápido". Observa-se que neste nível de ensino, a curiosidade, a necessidade de falar sobre suas experiências religiosas e saber respostas de perguntas vitais: "de onde eu venho?" "para onde eu vou?".

Essas perguntas permitem diálogos que fortaleçam as ideias que os alunos já trazem como experiência ou são respostas que querem ouvir do professor para terem certeza. Nesta fase não há muitos questionamentos sobre a veracidade das respostas, o importante é ter uma explicação para as dúvidas. Percebe-se uma fé que ofereça resposta direta e inquestionável, se os pais, avós, ou professores falaram isto é tido como verdade única a ser seguida. 
Religare, ISSN: 19826605, v.15, n.1, agosto de 2018, p.127-155.

Ao solicitar que o aluno faça a sua conversa com o transcendente através de uma oração, para fazer pedidos ao papai do céu, ou outros agradecimentos, a criança prontamente realiza a tarefa e parece não haver dúvidas sobre a fé que estão expressando nessas orações. Os alunos que não trazem esta experiência como bagagem e experiência familiar, procuram rapidamente encontrar sua maneira de também realizar sua oração ou conversa com o transcendente. Essa posição do docente favorável à realização de orações em sala de aula é motivo de polêmica na pesquisa em educação:

A sala de aula não é lugar de celebração e podemos dizer isto com todo o respeito. Mas a sala de aula, como o nome já diz é lugar de aula. Para o professor ainda é difícil separar o fenômeno religioso como objeto de estudo dos conteúdos e ensinamentos das expressões religiosas. (RODRIGUES et. al, 2011, p. 187)

Outro fator que observamos e merece ser ressaltado no nível de ensino das Séries Iniciais, refere-se à aceitação de diferentes respostas para as mesmas perguntas religiosas. Quando se traz a ideia de que existem muitas respostas para uma mesma pergunta, eles percebem que eles trazem experiências diferentes a partir das realidades familiares e comunitárias com as quais convivem.

Para exemplificar reproduzimos algumas perguntas que foram formuladas durante aulas recentes de Ensino Religioso: "Para onde vamos depois que morremos?" e encontramos diferentes respostas. Alguns respondem: "Meu pai disse que a gente vai pro céu"; "Minha mãe disse que a gente vira uma estrelinha no céu"; "Me falaram que a gente reencarna em outra pessoa"; "Se a pessoa for do mal, ela vai para o inferno, onde só tem fogo e escuridão". O aluno, ao perceber que não é questionado na sua resposta, sobre sua veracidade, se sente respeitado em sua fé naquilo que diz e sente sua fé fortalecida. Ao mesmo tempo, ele consegue compreender e aceitar que cada um pode ter a sua resposta. Nesta experiência se percebe como é importante o respeito às diferentes visões religiosas que cada um apresenta e que é fundamental para o convívio e respeito entre os diferentes. 
Religare, ISSN: 19826605, v.15, n.1, agosto de 2018, p.127-155.

Parece que, nessa etapa inicial do ensino fundamental, o Ensino Religioso tem a peculiar capacidade de contribuir para o aprendizado de um dos princípios educacionais como previsto pela LDB em seu artigo $3^{\circ}$, inciso IV, qual seja, o de promover o "respeito à liberdade e apreço à tolerância" (BRASIL, 1996). O Ensino Religioso ajuda as crianças no aprendizado do respeito à liberdade das religiões e a desenvolver o que é mais difícil: o apreço, o gosto, o prazer pessoal em praticar a tolerância em relação às concepções divergentes no campo religioso.

Quando partimos para as aulas de Ensino Religioso nas séries finais do Ensino Fundamental, estamos diante de um público que inicia o processo de questionamentos, não mais aceitando "cegamente" os dogmas que até este momento eram inquestionáveis. Nesta fase da vida, surgem as primeiras e fortes manifestações sobre ateísmo e alguns adolescentes adotam a forma ateísta de ver as coisas e o mundo que lhes parecem fazer mais sentido, dando-lhes maior credibilidade que as crenças religiosas ouvidas e "impostas" até então. Questionamentos sobre a origem das coisas e do mundo, "se foi Deus o responsável pela criação do mundo, quem então criou Deus?"; sobre a ideia de ser a religião ou Deus uma criação cultural dos seres humanos. Questionamentos sobre a possibilidade de não haver nada após a morte, que tudo simplesmente acaba quando a morte chegar, até porque nada está comprovado sobre a realidade pósmorte. A ideia de que Deus não seria tão onipotente, pois na realidade existe muita maldade e miséria, etc. Todos estes questionamentos deixam a vida do adolescente ainda mais confusa, os conceitos que ele trazia sobre os diversos elementos explicados pelas religiões, agora se lhes aparece como uma incógnita.

Como professor de Ensino Religioso, mantendo um olhar aberto, onde todas as respostas são acolhidas e se tornam uma possibilidade de vir a ser, não sendo desrespeitoso em relação ao posicionamento dos alunos, estes questionamentos podem ser ponto de partida para um diálogo prazeroso, que eleva o nível de compreensão que existe no aluno, que mexe com o sentido que cada educando tenta dar para os mistérios da vida. Essa postura dialogal e não dogmática do docente de Ensino Religioso, ao mesmo tempo, atrai os 
Religare, ISSN: 19826605, v.15, n.1, agosto de 2018, p.127-155.

adolescentes para o diálogo e o debate e pode, exatamente pela aceitação, desacomodar antigos conceitos religiosos da infância. Afinal, superar o pensamento religioso infantil não seria uma boa postura pedagógica que prepara para um novo desenvolvimento do pensamento religioso?

A reformulação de conceitos religiosos que os estudantes trazem ou adquirem no contexto social em que vivem, ou as novas ideias religiosas que cada um vai construindo, a partir dos conhecimentos e do diálogo entre diversas crenças, pode ser uma forma de superação da "crise existencial e de fé" que cada educando vai passar e, talvez, deva passar na construção de uma fé religiosa mais amadurecida e pessoal. Esta fase de transformação conceitual sobre os elementos das religiões nem sempre é compreendida e bem vista pelas famílias, de modo especial, as mais conservadoras. Nas entrevistas com as famílias sempre há o questionamento dos pais sobre as atitudes e os pensamentos que os filhos, nesta fase escolar, vão trazendo da escola para as suas casas. "Meu filho diz que não acredita mais em Deus", "Minha filha não quer mais ir à missa, diz que tudo é chato e sem sentido na igreja". A esperança dos pais é que esta fase passe e tudo volte ao normal. Os pais, especialmente nas escolas confessionais, costumam pressionar o professor de Ensino Religioso, exigindo que esta disciplina se transforme em aulas de catequese e, assim, o docente devolva a seus filhos àquela disposição religiosa infantil que aos pais parece ter sido perdida. Talvez a única resposta honesta do docente de Ensino Religioso seja a do apóstolo Paulo: “Quando eu era menino, falava como menino, pensava como menino e raciocinava como menino. Quando me tornei homem, deixei para trás as coisas de menino" (1 Coríntios 13:11).

Se os pais desejarem, de fato, que seus filhos se sintam atraídos e não entediados para participarem da missa, talvez o docente de Ensino Religioso possa incentivar as famílias para que ajudem suas comunidades religiosas no desenvolvimento de liturgias, missas, celebrações ou cultos mais atraentes e agradáveis para os adolescentes. Uma das atribuições dos docentes, segundo o artigo 13, inciso VI da LDB, é "colaborar com as atividades de articulação da 
Religare, ISSN: 19826605, v.15, n.1, agosto de 2018, p.127-155.

escola com as famílias e a comunidade" (BRASIL, 1996). Paróquias, igrejas locais, ou outras organizações religiosas são parte da comunidade do entorno escolar.

Não é função da escola e nem do Ensino Religioso assumir funções catequéticas, missionárias ou doutrinárias para qualquer religião ou igreja. $\mathrm{O}$ artigo 33 da LDB veda a prática do proselitismo religioso no âmbito da escola pública ao exigir que esta disciplina curricular e os seus docentes assegurem "o respeito à diversidade cultural religiosa do Brasil" (BRASIL, 1996). O respeito inclui, por óbvio, a peculiar articulação dessa disciplina com as organizações religiosas presentes no entorno da escola e com as confissões religiosas eventualmente adotadas pelo corpo discente da escola, desde que todas essas religiões se disponham a cooperar com as funções educacionais e socializadoras da escola. Neste ponto da relação entre a escola e a comunidade religiosa se deve observar a máxima liberdade, desde que estas religiões apreciem a tolerância que seria, de fato, a restrição mínima.

Muitos adolescentes, ao ingressarem no Ensino Médio, voltam a ver e a ter sentido nas práticas e doutrinas religiosas que aprenderam desde pequenos; outros, no entanto, realmente se tornam muito questionadores de tudo e não aceitam nenhuma forma de crença, adotando apenas o que imaginam ser a ciência como a única forma de conhecimento humano capaz de dar-lhes sentido para suas vidas. Ou seja, praticam o que desde 1919, Max Weber denominava de desencantamento do mundo:

O destino de nossos tempos é caracterizado pela racionalização e intelectualização e, acima de tudo, pelo "desencantamento do mundo". Precisamente os valores últimos e mais sublimes retiraram-se da vida pública, seja para o reino transcendental da vida mística, seja para a fraternidade das relações humanas diretas e pessoais. [...] Se tentarmos reconstruir intelectualmente novas religiões sem uma profecia nova e autêntica, então, num sentido íntimo, resultará alguma coisa semelhante, mas com efeitos ainda piores. E a profecia acadêmica, finalmente, criará apenas seitas fantásticas, mas nunca uma comunidade autêntica. (WEBER, 1974, p. 182-183) 
Religare, ISSN: 19826605, v.15, n.1, agosto de 2018, p.127-155.

Essa posição individualista ensimesmada que, eventualmente, o educando possa assumir a partir desta determinada concepção de ciência não parece compatível com o princípio já mencionado de apreço à tolerância que pressupõe o convívio comunitário com as diferenças culturais religiosas. Em consequência do fato de ser uma disciplina do currículo escolar, os fundamentos epistemológicos e os conteúdos do Ensino Religioso

não se referem mais, de forma preferencial, ao saber teológico, mas, sim, ao saber antropológico e às expressões culturais portadoras de religiosidade. Não é mais, e sobretudo não é prioritariamente, uma iniciação e formação de adeptos de determinada Igreja, mas, sim, um elemento indispensável de formação integral dos alunos. (RUEDELL, 2007, p. 34)

Assim, o Ensino Religioso pode assumir a função crítica em relação ao conhecimento científico para o qual o ensino fundamental prepara seus educandos. O estudo científico da religiosidade humana, "quando abertos e integrados à realidade viva da experiência religiosa que emerge da dimensão religiosa do ser humano, extrapolam seu restrito confinamento científico e contribuem, sob forma nova, para a educação" (RUEDELL, 2007, p. 39).

Nas séries finais do Ensino Fundamental, são exploradas várias áreas de conhecimentos a partir da apresentação das grandes religiões e suas ramificações o que exige uma formação especializada de nível superior. Não há um padrão nacional para a formação de docentes de ensino religioso, pois “o Parecer no 97/99 do CNE, que versa sobre as solicitações de autorização e reconhecimento de cursos de Licenciatura em Ensino Religioso, traz como conclusão a impossibilidade de criação de diretrizes curriculares nacionais para a orientação desses cursos" (AMARAL, et. al., 2017, p 277). Não é simples desenvolver atividades letivas capazes de apresentar as características das grandes religiões do mundo e suas ramificações presentes em nossa realidade nacional de forma sucinta e objetiva desde o ponto de vista científico; de forma respeitosa e não 
Religare, ISSN: 19826605, v.15, n.1, agosto de 2018, p.127-155.

proselitista desde o ponto de vista religioso. O que não é uma tarefa simples e, portanto, cabe perguntar:

seria viável para o professor de ensino religioso, que em média tem um tempo de aula semanal, abordar conteúdo tão extenso. Sabemos que a história das religiões é um tema muito vasto, sendo as grandes religiões abraâmicas marcadas por eventos de dimensões difíceis de serem abordadas, sem simplificações, em curto período de tempo. O problema se complexifica mais se incluirmos os credos não monoteístas e as doutrinas religiosas sincréticas. (AMARAL et. al., 2017, p. 284)

Apesar desse problema, os educandos demonstram um interesse enorme em conhecer estas diferentes formas de crenças presentes nas diversas culturas do mundo. Aqui o Ensino Religioso tem a oportunidade de atender a peculiar curiosidade epistêmica dos estudantes. A caracterização da disciplina como área de conhecimento produz uma consequência significativa para a formação integral do ser humano: o reconhecimento e o apreço pelo valor da diversidade. Desta forma, o educando pode aprender na escola a se tornar mais culto, mais respeitoso e tolerante frente à diversidade de crenças e dogmas. Brighouse avalia que a clássica separação entre a escola pública laica e secular e a escola privada religiosa e confessional, ocorrida nos Estados Unidos, acabou por polarizar a cidadania do país, dividindo e até antagonizado cidadãos secularizados contra cidadãos religiosos fundamentalistas e vice-versa. O convívio democrático exige superar essa polarização e, nesta perspectiva, o pedagogo norte-americano propõe que o

contato com opiniões morais é melhor quando se permite que os seus proponentes se dirijam às crianças no ambiente controlado da sala de aula. Embora o argumento instrumental esteja ligado ao humanismo liberal, que é anátema para muitos sectários religiosos, é provável que a implementação da educação que facilite a autonomia exija uma atitude nuançada para com a exposição da criança à religião na escola. A criança só poderá ser autônoma na aceitação ou rejeição de pontos de vista religiosos se vivenciar uma discussão séria. (2011, p. 24) 
Religare, ISSN: 19826605, v.15, n.1, agosto de 2018, p.127-155.

Na experiência dos sistemas de ensino nos Estados Unidos, conforme a opinião deste pedagogo, “a escola pública oferece ensino sem dimensão espiritual enquanto a sectária oferece ensino sem dimensão secular" (BRIGHOUSE, 2011, p. 84). O professor de Ensino Religioso pode perceber a vontade de muitos educandos de ir além do conhecimento sobre uma determinada religião, eles querem experienciar alguns rituais e movimentos. Como exemplo da prática, pode-se citar que no estudo da religião budista, descobre-se que um dos seus principais rituais é a meditação. Ao realizar, em uma aula, durante cinco minutos, um momento de meditação, este ato foi acolhido e realizado por todos e, posteriormente, em todas as aulas queriam que se fizesse meditação, alegando os alunos que isto trazia paz e tranquilidade para o espírito. A capacidade de aprender com o outro e permitir que o diferente nos ajude a apreendê-lo é uma possibilidade do Ensino Religioso obrigatório em escolas públicas e privadas que, se bem aplicada e executada pelos seus docentes, certamente, contribuirá para evitar a fragilidade democrática que o mencionado pedagogo crítico identificou no sistema de ensino norte-americano.

Ao estudar a diversidade das religiões, abrem-se portas para aceitação das diversas manifestações religiosas que cada educando e suas famílias trazem da sua realidade privada para a o espaço público da educação escolar. Quando por exemplo um aluno, fala da sua experiência religiosa, os olhares e a atenção redobram, percebe-se uma sede entre os alunos em querer muito acreditar em algo, de saber como funciona, como se faz para participar. Cito como exemplos, uma aluna de $9^{\circ}$ ano, na ocasião em que estudou-se as religiões afro-brasileiras e suas características, relatou sua inusitada experiência de ter feito uma cirurgia espiritual em uma terreira de Umbanda. Relatou aos colegas e ao docente que, com a ajuda do pai de santo e dos orixás, declarou ter obtido a cura de sua doença. Um menino do $8^{\mathrm{o}}$ ano, ao estudarmos a doutrina espírita, também relatou sua cura a partir de uma cirurgia espiritual realizada por médiuns que estavam reunidos em outro espaço físico, diferente do espaço físico em que o estudante se 
Religare, ISSN: 19826605, v.15, n.1, agosto de 2018, p.127-155.

encontrava. Esses dois relatos demonstraram ser momentos significativos para se compreender as diversas possibilidades e formas pelas quais as pessoas procuram depositar sua fé. Outro fato interessante que deve ser mencionado foi o caso de uma menina do $2^{o}$ ano do Ensino Médio. Ela sempre costumava criticar todas as religiões e também as pessoas que se submetiam, seguiam e vivenciavam alguma religião. Ela mudou de opinião e comportamento para com os crentes a partir do momento em que começou a namorar um menino fora da escola e que era seguidor da religião judaica. Ela aceitou o estilo e filosofia de vida que o menino seguia, mudando sua visão a respeito da influência das religiões sobre a vida das pessoas.

A partir destas experiências, das partilhas de vivências dos educandos, dos conhecimentos obtidos em aula sobre a diversidade religiosa, que percebemos a riqueza de participar de aulas sobre este misterioso universo religioso. Esses casos não serviram simplesmente para ilustrar as possibilidades das religiões e para ensinar o respeito à diversidade. Eles afetam todo o currículo escolar e este é um desafio para o Ensino Religioso, quando os casos religiosos provocados pelo casal de namorados de religiões muito diversas, ou das curas espirituais que se oferecem como alternativas ao tratamento médico convencional. São dois casos que levantam dois problemas da sociedade e da ciência contemporânea. Como o Ensino Religioso deve acatar a proibição do proselitismo e, ao mesmo tempo, permitir que os alunos expressem sua fé de forma livre e autônoma? Como o Ensino Religioso pode enfrentar o fato de ele mesmo ser uma área do conhecimento científico e, portanto, compartilhar com as demais disciplinas do compromisso com a racionalidade das diferentes ciências. Por outro lado, a presença do Ensino Religioso pode representar uma forma de resistência ao fato que se constata nos Estados Unidos de "muitas escolas públicas estão imbuídas dos valores materialistas da cultura de consumo" (BRIGHOUSE, 2011, p. 90) como se fossem uma religião secular, que no Brasil parece se apresentar com mais frequência em escolas privadas não confessionais. Em termos mais concretos 
Religare, ISSN: 19826605, v.15, n.1, agosto de 2018, p.127-155.

a escola que adota a meta de facilitar a autonomia e a cidadania democrática deveria tomar providências para garantir que a população estudantil fosse mista em relação à religião e que o seu éthos estimulasse o real envolvimento de crianças provindas de ambientes diferentes. Por conseguinte, embora eu não seja otimista e não ache que o sistema escolar dos Estados Unidos evoluirá para o tipo de sistema mais complexo encontrado em toda a Europa, uma das vantagens de delegar o controle local é permitir escolar e distritos escolares específicos desenvolverem um éthos muito mais inclusivo e multirreligioso. (BRIGHOUSE, 2011, p. 91-92)

Estas poucas experiências religiosas descritas acima, nas séries finais do Ensino Fundamental, são experiências vividas em escolas confessionais. É possível também trazer presente a realidade experimentada em escola pública nas séries finais do ensino fundamental como professor de ensino religioso no município de Sapucaia do Sul, na região metropolitana de Porto Alegre/RS. O docente informou que não imaginava a alegria e o entusiasmo como foi acolhido na condição de professor de Ensino Religioso. Ao trazer alguns conhecimentos específicos presentes nas diversas religiões do mundo, pode perceber a carência e ausência de informações sobre as mesmas, fazendo aumentar ainda mais o gosto e o prazer dos estudantes em participar das aulas. Logo pode constatar que a maioria das turmas, apenas tiveram aulas de Ensino Religioso com professores formados em outras áreas de atuação, ou seja, a professora de história, de ciências e artes, que tinham horas sobrando, completavam suas cargas horárias com algumas horas de Ensino Religioso. Neste cenário diferente, atingindo um público mais carente e vulnerável socialmente, também se percebe a forte ligação que a religião exerce na vida dos educandos. A maioria participava de cultos, terreiras, centros espíritas e missas semanalmente.

Nas escolas em que atuava e atua o docente de Ensino Religioso, seguidamente os alunos lhe perguntavam: Hoje vai ter debate? A aula de Ensino Religioso era esperada pelos estudantes como mais uma oportunidade que a escola oferecia para realizar debates sobre temas sociais, culturais e ambientais, 
Religare, ISSN: 19826605, v.15, n.1, agosto de 2018, p.127-155.

pois é um espaço onde todos podem se expressar e manifestar opiniões sobre as diversas temáticas. Entre as temáticas trazidas nas diversas séries finais do Ensino Fundamental estão presentes questões como bullying, drogas, orientação sexual, aborto, violência, legalização da maconha, racismo, cultura machista, feminismo, inclusão, filosofias de vida, liderança, empreendedorismo e outros. São temas transversais que são trabalhados especialmente na disciplina de Ensino Religioso, pois as outras disciplinas - principalmente matemática e português - precisam vencer o conteúdo programático e não têm tempo para trabalhar temáticas transversais.

Nestes diálogos e debates se percebe a importância da formação propiciada pela disciplina Ensino Religioso para o protagonismo juvenil, contribuindo para a formação de cidadãos mais críticos e ativos, pois o debate que se inicia em sala de aula, muitas vezes segue nas conversas nos corredores, com estudantes de outras turmas e também nos recintos familiares, onde muitos se sentem mais à vontade para poder apresentar suas reflexões e críticas sobre os diversos posicionamentos das pessoas diante de uma temática abordada. Percebe-se a necessidade que a maioria dos estudantes tem de esclarecimento e convencimento sobre os pressupostos encontrados no nosso dia a dia. Alguns conseguem argumentar e sustentar suas ideias diante dos questionamentos enquanto outros, observam, escutam e tentam se fortalecer nos seus posicionamentos ou então são convencidos à mudança. E no final, novamente destacam "quando vai ser o próximo debate?", ou seja, demonstram um enorme desejo e interesse em estar conscientes ou mesmo cientes sobre assuntos diversos presentes em nossa cultura social.

De modo especial, no Ensino Médio, o nível de debate sobre temáticas sociais se torna bem mais profundo, pois os estudantes são instigados a realizarem pesquisas para fundamentar os seus argumentos, ou seja, o debate já não é realizado mais a partir de pressupostos do consenso, do senso comum, do conhecimento prévio, sem necessidade de buscar antecipadamente uma fundamentação científica. Nos adolescentes do Ensino Médio, percebe-se uma 
Religare, ISSN: 19826605, v.15, n.1, agosto de 2018, p.127-155.

"sede" maior em saber mais sobre os diversos assuntos, pois já estão entrando na vida adulta, exigindo-se um posicionamento mais forte e consciente nos diversos espaços sociais. É o início de um protagonismo juvenil que cria asas e vai enfrentando imposições, preconceitos e se confrontando com as diversas ideologias que estão em disputa e concorrência na sociedade política, como é próprio das democracias.

Também se destaca no Ensino Médio o retorno da fé para muitos estudantes, principalmente, entre aqueles que colocavam em dúvida a crença religiosa nas séries Finais do Ensino Fundamental. Muitos começam a se envolver em algum grupo, começam a participar de algum tipo de filosofia de vida e, sim, passam a perceber a necessidade de estarem ligados a algum movimento que traga mais sentido e motivação para viver. Por óbvio, este "retorno à fé" parece ser facilitado nas escolas privadas confessionais que mantém iniciativas da pastoral da juventude ou outras formas de atendimento religioso aos jovens estudantes. A pastoral, no entanto, não é um componente curricular. Por óbvio, considerando a função de a escola atuar na socialização das novas gerações, a pastoral pode ou não se integrar ao Ensino Religioso e/ou outras disciplinas curriculares.

\section{A experiência de ser professor de Ensino Religioso e sua (des)valorização no curriculo escolar e na licenciatura especifica}

O objetivo desta segunda parte do artigo é partilhar a experiência do pesquisador em educação relacionando, de um lado, a decisão da política educacional de incluir o Ensino Religioso no currículo do Ensino Fundamental com, de outro lado, a experiência docente relatada na primeira parte. Assim, o artigo dá continuidade à proposta de "discutir a identidade pedagógica do Ensino Religioso" como um

desafio que é imposto para se pensar na formação dos docentes dessa área de Ensino. E propor e discutir características pedagógicas para Ensino Religioso significa analisar e 
Religare, ISSN: 19826605, v.15, n.1, agosto de 2018, p.127-155.

compreender essa disciplina no conjunto de teorias da educação. A aproximação entre os saberes acadêmicos e os saberes práticos demanda muitas pesquisas para contribuir na formação teóricoepistemológica do professor, pois é essa formação que lhe permitirá estabelecer relações mais complexas da prática. (RODRIGUES et. al., 2011, p. 190)

Em seu depoimento, o professor de Ensino Religioso afirma que exerce essa função porque

é algo que me realiza muito, profissionalmente. O campo de atuação enquanto educador abrange uma ampla área de conhecimento cultural e social, onde posso participar da formação integral da vida de inúmeros adolescentes, um espaço que se inspira e respira muita vida, muita transformações humanas, percebo muito potencial e dinamismo coletivo, enfim, o desafio é intenso e não se torna rotina.

Por outro lado, o docente de Ensino Religioso reconhece que, ao mesmo tempo, ocorre também uma desvalorização profissional porque a disciplina não tem seu devido reconhecimento enquanto área de conhecimento e espaço de aprendizado. São muito comuns comentários de familiares e discentes que afirmam: "Ensino Religioso não reprova, por isso não é importante"; “Não cai no Vestibular"; "Serve para ensinar moral e civismo na escola". Por óbvio, essas informações possuem vínculos verdadeiros com a realidade educacional.

Também é comum ouvir que poucas pessoas querem ser professor de Ensino Religioso, geralmente, quem assume essa disciplina é um docente de outras áreas do conhecimento que não conseguem completar a carga horária com as turmas da disciplina de sua especialidade. Parece, portanto, que no senso comum do Magistério, o Ensino Religioso é uma disciplina que qualquer docente pode ministrar. Também causa desalento entre os docentes de Ensino Religioso quando perceberem que a coordenação pedagógica ou o diretor da Escola preferem utilizar as aulas de Ensino Religioso para resolver as mais diversas situações que atrapalham a rotina da escola, mas que não tem nenhuma ligação epistemológica com a disciplina. Também é desalentador, especificamente nas 
Religare, ISSN: 19826605, v.15, n.1, agosto de 2018, p.127-155.

escolas privadas, quando o docente da disciplina percebe que a aula de Ensino Religioso é valorizada desde que trate com prioridade a religião com a qual a mantenedora da escola se identifica. Algumas escolas confessionais, em clara contrariedade com a LDB, impõem sua doutrina religiosa como conteúdo privilegiado ou, mais grave ainda, como único conteúdo a ser ministrado. Felizmente não é o caso da experiência docente do primeiro autor do artigo.

A reação e o comportamento das famílias a partir da experiência do Ensino Religioso na vida dos filhos, também podem contribuir para a desvalorização da disciplina. Algumas famílias esperam seus filhos ou filhas possam receber uma formação religiosa na escola confessional na qual foram matriculados. Tais famílias incluem a religião da mantenedora da escola entre as razões para a escolha da matrícula. Nesses casos, para essas famílias, nem sempre o Ensino Religioso produz o resultado esperado, ou seja, alguns pais esperam que seus filhos recebam da escola, a doutrinação religiosa que a própria família e sua comunidade religiosa não conseguem oferecer às novas gerações. Em geral, as escolas confessionais observam a legislação educacional e não se utilizam do Ensino Religioso para práticas catequéticas. Mesmo assim, esse desejo frustrado das famílias provocam conflitos desnecessários com o docente de Ensino Religioso que passa a ser visto por tais famílias como não sendo um bom fiel daquela Igreja ou denominação religiosa.

Como exemplo, narra-se o caso de uma mãe, cujo filho estudava no $7^{\circ}$ ano do Ensino Fundamental e o mesmo recebeu no boletim uma nota abaixo da média: "Mas meu filho vai todo domingo na missa, como ele foi tão mal em Ensino Religioso? A família é toda católica, desde pequeno ele sempre participa de tudo. Não entendo". Percebe-se nesta fala que a expectativa em relação ao Ensino Religioso é totalmente doutrinal, a família não percebe que o Ensino Religioso abrange uma área de conhecimento muito ampla e não se reserva a uma determinada religião.

Por outro lado, há o exemplo de famílias que elogiam a disciplina e o docente como, por exemplo, a família que relatou sobre o entusiasmo do filho em 
Religare, ISSN: 19826605, v.15, n.1, agosto de 2018, p.127-155.

querer participar das aulas de Ensino Religioso, pois vai ter um determinado debate, ou quando vai ter o estudo de uma religião que é diferente do cotidiano da família e isto é visto positivamente. Nesse caso, o professor sente uma satisfação profissional muito grande. Destaca-se também o reconhecimento da importância do estudo das diversas religiões por parte das famílias quando elas mencionam a alegria que sentem quando o filho começa a relatar sobre as aulas no âmbito familiar, de modo especial, quando o estudo da religião é sobre aquela a que a família pertence. Algumas dessas famílias, inclusive, se colocam à disposição para oferecer palestras ou vivências na escola sobre a sua religião. Como exemplo, cito o pai de um aluno do $9^{\circ}$ ano, e que era Pai de Santo, e veio realizar uma conversa junto com a turma. Isto demonstra tanto por parte da escola como também da família, a prática da tolerância, do acolhimento e do respeito pelo diferente e a alegria de compartilhar os diferentes conhecimentos e, principalmente, a partilha das diferentes práticas religiosas que muitas vezes apenas são conhecidas através de pesquisas na internet ou na Biblioteca Escolar. O diálogo produz um conhecimento mais pessoal e profundo.

Também há famílias que valorizam o estudo de temáticas sociais, pois relatam que os filhos trazem para casa discussões e reflexões de cunho político e social e o quanto isso estaria ajudando na formação da personalidade do filho. Enquanto algumas famílias elogiam, outras começam a se preocupar, pois o filho não aceita mais qualquer imposição ou opinião familiar sobre a vida em sociedade. Alguns pais chegam a comentar que "meu filho quer ser um revolucionário, quer mudar todos em sua volta, está até difícil conversar com ele". Isso demonstra que as aulas de Ensino Religioso, além de ser uma área de conhecimento, é um espaço que desacomoda o adolescente, oferecendo um espaço onde se desperta para um sentido de vida maior, uma razão para viver e não viver atoa, um espaço de inspiração para novos projetos de vida, um espaço de pura transcendência. Afinal, a escola prepara cada criança para a vida democrática. Uma avaliação sobre a tradição educacional norte-americana parece 
Religare, ISSN: 19826605, v.15, n.1, agosto de 2018, p.127-155.

sugerir que inserção da disciplina Ensino Religioso no currículo escolar brasileiro pode produzir uma contribuição democrática valorosa.

Provavelmente, aprendemos mais sobre como se articulam os diversos modos de vida e se eles seriam adequados para nós por meio de contatos com quem vive de forma diferente. A escola que facilita a autonomia se constituirá de crianças e adultos vindos de diversos ambientes, com pontos de vista divergentes e sobre como levar a vida. Uma escola com crianças muçulmanas, hinduístas, ateias, católicas e judias será melhor do que outra em que todas as crianças são católicas. Mantendo-se iguais todos os outros fatores. Uma escola em que os professores têm fé e origem étnicas variadas e demonstram entusiasmos pessoais diversificados será melhor do que outra em que todos são "farinha do mesmo saco". (BRIGHOUSE, 2011, p. 21)

Esses poucos relatos e a reflexão de Brighouse permitem imaginar a dimensão acadêmica inerente ao problema da formação docente para a área do conhecimento do Ensino Religioso em nível superior. O problema foi identificado quando o Conselho Nacional de Educação recebeu os primeiros pedidos e solicitações de orientação de Instituições de Ensino Superior interessadas em organizar licenciaturas em Ensino Religioso. A prof. Eunice Durham, conselheira relatora, argumentou a partir da Lei 9.475/97 (BRASIL, 1997):

Em primeiro lugar, deve-se considerar que, atribuindo a lei aos diferentes sistemas de ensino, não só a definição dos conteúdos do ensino religioso, mas também as normas para habilitação e admissão dos professores, é impossível prever a diversidade das orientações estaduais e municipais e, assim, estabelecer uma diretriz curricular uniforme para uma licenciatura em ensino religioso que cubra as diferentes opções. (CNE/CP, 1999, p. 3)

A relatora conclui que "Não se contempla, necessariamente, um curso específico de licenciatura nesta área, nem se impede que formação possa ser feita por entidades religiosas ou organizações ecumênicas" (CNE/CP, 1999, p. 3). Assim, conclui a relatora "parece-nos impossível, sem ferir a necessária independência entre Igreja e Estado, estabelecer uma orientação nacional 
Religare, ISSN: 19826605, v.15, n.1, agosto de 2018, p.127-155.

uniforme que seria necessária para a observância dos processos atuais de autorização e reconhecimento" (CNE/CP, 1999, p. 4) destas licenciaturas. Desde então, com a aprovação do Parecer pelo Conselho Pleno do CNE e sua homologação pelo MEC, poucas oportunidades de formação em nível superior para o docente de Ensino Religioso foram oferecidas no país. Quase duas décadas depois de exarado este parecer permanece a

falta de orientações do MEC e do CNE sobre a formação docente para o ensino religioso, a responsabilização de municípios e estados pela definição de critérios de admissão de professores torna a disciplina - de oferta nacionalmente obrigatória - muito diversa de acordo com as determinações de cada ente federado, o que reflete na aceitação de diferentes tipos de habilitações de docentes. (AMARAL, et. al., 2017, p. p. 277)

Para Cury, a avaliação do Parecer, deve

recuperar a distinção nele posta em que se diferencia a formação da habilitação. A formação é aquela qualificação que se adquire ao término de um curso de ensino superior autorizado e expresso em um diploma em vista de uma presença no âmbito profissional. Já a habilitação é o reconhecimento de uma capacidade por uma autoridade pertinente compatível com uma atividade qualquer. Pode ser o registro em um órgão corporativo (supondo, no caso, formação prévia) ou uma carteira de motorista (não supõe formação de ensino superior). Assim, toda a formação prevê uma habilitação, mas nem toda habilitação supõe uma formação de ensino superior. No caso do ensino religioso, dada a sua natureza peculiar, em outras legislações, essa habilitação era dada por uma autoridade eclesiástica. O Parecer não impede que formação possa ser feita por entidades religiosas ou organizações ecumênicas ... evitando que o Estado interfira na vida religiosa da população e na autonomia dos sistemas de ensino. (2018, p. 324)

Essa indefinição do órgão gestor do sistema federal de ensino não resolveu a contradição entre a laicidade da educação estatal decorrente da clássica separação republicana entre igreja e estado, de um lado e de outro, a necessidade de os sistemas de ensino oferecerem a disciplina Ensino Religioso como 
Religare, ISSN: 19826605, v.15, n.1, agosto de 2018, p.127-155.

componente obrigatório do currículo escolar, mesmo que de matrícula facultativa. Essa contradição é mais acentuada nas universidades públicas que, mesmo considerando sua condição de entidade estatal, não se omitem na oferta desta formação profissional.

Existem cursos de Licenciatura em Ciências da Religião em oito universidades públicas brasileiras: Universidade Estadual do Maranhão (Uema), Universidade Estadual de Montes Claros (Unimontes), Universidade Estadual do Pará (Uepa), Universidade Estadual do Rio Grande do Norte (UERN), Universidade Estadual Vale do Acaraú (UVA), Universidade Federal de Juiz de Fora (UFJF), Universidade Federal da Paraíba (UFPB) e Universidade Federal de Sergipe (UFS). (AMARAL, et. al., 2017, p. p. 277-278)

Evidentemente algumas igrejas e movimentos ecumênicos com maior capacidade de articulação acadêmica e de participação responsável junto aos órgãos gestores da educação nos estados e municípios, organizaram, na medida de suas possibilidades institucionais e de acordo com aqueles órgãos públicos, cursos de licenciatura em Ensino Religioso

Em 2001 foi publicada pela imprensa oficial de SC a Proposta Curricular de Santa Catarina: Implementação do Ensino Religioso, resultado do trabalho desenvolvido por uma comissão constituída por representantes dos educadores das três Universidades que ofertavam Curso de Licenciatura em Ensino Religioso, dos Sistemas de Ensino e do Conselho de Ensino Religioso do Estado de SC/CONER/SC. Os encontros de estudo e elaboração do documento, sinalizações para (re) conhecer novos caminhos e construir outros mapas formadores aconteceram no decorrer do ano de 1999.

No ano de 2003, durante a realização do II Seminário Catarinense de Ensino Religioso, realizado nas dependências da Universidade do Planalto Catarinense/UNIPLAC, foi criada a Associação de Professores de Ensino Religioso do Estado de SC/ ASPERSC. A Universidade Comunitária da Região de Chapecó/ UNOCHAPECÓ e o Centro Universitário Municipal de São José/USJ também criaram seus cursos de licenciatura em ER no ano de 2008. (OLIVEIRA; KOCH, 2012, p. 469-470) 
Religare, ISSN: 19826605, v.15, n.1, agosto de 2018, p.127-155.

A Universidade Regional de Blumenau/FURB, por sua vez, o Curso de Ciências da Religião - Licenciatura em Ensino Religioso ${ }^{3}$, com o objetivo geral de

proporcionar um referencial teórico-metodológico que possibilite uma leitura e compreensão críticas dos fenômenos religiosos na diversidade cultural, contribuindo para a construção de uma sociedade justa, solidária e livre, que reconheça na alteridade a dignidade de todas as formas e expressões de vida. (OLIVEIRA; KOCH, 2012, p. 473)

As contradições entre, de um lado, a exigência de as escolas oferecerem a disciplina Ensino Religioso e, de outro, a inexistência de orientações nacionais para a licenciatura em Ensino Religioso incide negativamente sobre as demais políticas educacionais, como, por exemplo, é o caso do Programa Institucional de Bolsas de Iniciação à Docência (PIBID) que não prevê a disciplina Ensino Religioso (OLIVEIRA, 2018, p. 67).

O Ensino Religioso, na história da legislação educacional brasileira, já passou por várias mudanças. Os docentes comprometidos com essa disciplina já desenvolveram diversas inovações e produziram metodologias de ensino mais ou menos eficazes na busca do conhecimento sobre o fenômeno religioso, trazendo sempre novos desafios e reflexões sobre sua melhor aplicabilidade no cotidiano escolar.

Este novo olhar do Ensino Religioso, definido pela atual LDB como "laico", sem proselitismo, é um espaço que dialoga com as ciências, com e entre as igrejas e religiões, com e entre as famílias como exigência da própria laicidade da educação pública brasileira:

Com esse conjunto, pode-se afirmar que os valores laicos estão dispostos em dois níveis: um negativo e outro positivo, dialeticamente relacionados. Negativo no sentido da desconstrução dos preconceitos, das discriminações com relação a indivíduos e a minorias e o da redução das desigualdades

\footnotetext{
${ }^{3}$ Veja a apresentação do curso em

http://www.furb.br/web/1771/cursos/graduacao/cursos/ciencias-da-religiao/apresentacao
} 
Religare, ISSN: 19826605, v.15, n.1, agosto de 2018, p.127-155.

sociais e das disparidades regionais. Positivo, no sentido da afirmação da tolerância, da aceitação e do reconhecimento. (CURY, 2018, p. 318)

Essa dialética entre a ciência, a religião, os valores republicanos e a ética reconhecem o fenômeno religioso como um elemento que constitui nossa cultura, aumentando desta forma o respeito à diversidade de crenças e busca reduzir a intolerância religiosa. Essa postura política de convivência social republicana, no entanto, também carrega sua contradição: o proselitismo é o fundamento do estado democrático. Os partidos políticos são agências de proselitismo, disputam entre si pela decisão do voto e pela decisão de filiação dos eleitores. Nesse sentido democrático, o direito proselitismo é uma característica positiva e uma necessidade para o aperfeiçoamento da disputa partidária que qualifica a democracia, nos limites da racionalidade dialógica e da ética. A disputa proselitista, no entanto, tem e deve ter limites e regras para que seja uma boa prática de qualificação do espaço público, posto que práticas proselitistas na disputa democrática não devam restringir, coagir ou mesmo influenciar por meios sub-reptícios a liberdade de consciência da cidadania que é, por sua vez, o próprio pressuposto da possibilidade de livre filiação partidária. A proibição do proselitismo no Ensino Religioso é uma garantia para que a educação pública, exercida em nome do estado nas instituições de ensino estatais ou privadas, não pode limitar de nenhum modo a liberdade de crença da cidadania. É justo, portanto, que o estado democrático de direito prive o professor do seu direito de fazer proselitismo religioso no espaço público da sala de aula, mas não restringe essa liberdade na sua vida privada e social fora da escola onde trabalha. No mesmo sentido vale perguntar se é justo que o estado laico ofereça de forma pedagógica coerente, o Ensino Religioso sem exigir habilitação nacional padronizada para o exercício deste Magistério nos sistemas públicos de ensino? Nesse caso, parece não ser justo!

Em síntese, diante da acirramento das disputas ideológicas e mesmo das guerras religiosas, parece conveniente assumir esse "desafio democrático" 
Religare, ISSN: 19826605, v.15, n.1, agosto de 2018, p.127-155.

porque o Ensino Religioso "nas escolas públicas provoca o encontro entre esses dois direitos - o de respeito à liberdade de consciência, bem como o de igualdade entre as religiões" (DINIZ et. al., 2010, p. 25). As autoras advogam a noção de “justiça religiosa" como uma característica da laicidade, pois ela

diz respeito não apenas ao direito de professar ou não uma religião e ao dever de neutralidade do Estado em matéria religiosa, mas também a como garantir o igual direito de representação pelas comunidades religiosas nos espaços públicos do Estado. [...] a justiça religiosa é um dos princípios básicos para a promoção da cultura dos direitos humanos em nações cuja laicidade se expressa pela pluriconfessionalidade. Nossa expectativa é que o livro demonstre a importância de a justiça religiosa ser um dos fundamentos éticos para a operacionalização do ensino religioso nas escolas públicas brasileiras. (DINIZ et. al., 2010, p. 29)

A igualdade entre e das religiões não pode, portanto, ser um valor ético absoluto para assegurar uma "justiça religiosa" considerando que o

\begin{abstract}
Estado laico não é ateu nem religioso. Não deve perseguir as religiões, nem promover a religiosidade. Tratando-se de estabelecer regras de convivência, deve buscar o mínimo de restrição com o máximo de liberdade, sempre focando o respeito à diversidade religiosa, contemplando crentes e não-crentes. Em outras palavras, liberdade de expressão religiosa não se confunde com liberdade de opressão religiosa. (LOREA, 2008, p. 160)
\end{abstract}

\title{
Considerações Finais
}

Diante do complexo cenário educacional onde está inserida a disciplina Ensino Religioso, com suas contradições e indefinições, faz-se urgente que a pesquisa na área da Educação discuta sobre a formação e a habilitação do docente para esta disciplina escolar. Não parece adequado para os padrões pedagógicos atuais que docentes de qualquer licenciatura sejam habilitados para lecionar essa disciplina, descaracterizando ou até mesmo desvalorizando uma área de conhecimento que precisa desenvolver uma epistemologia científica peculiar 
Religare, ISSN: 19826605, v.15, n.1, agosto de 2018, p.127-155.

sobre a diversidade religiosa, a pluralidade de conhecimentos e sobre o diálogo fraterno entre diferentes teorias e crenças religiosas nas salas de aula do Ensino Fundamental. Na atual conjuntura brasileira, o Ensino Religioso e os seus docentes podem contribuir, especificamente, no combate e prevenção de atentado impetrado à democracia por fundamentalistas religiosos incapazes de reconhecer a dignidade humana em quem não partilha de sua determinada crença.

Este desafio para o Ensino Religioso está inserido no contexto político brasileiro e mundial de crise de reconhecimento e de valorização popular da democracia e do estado de direito. Nas primeiras décadas deste segundo milênio, as igrejas e religiões ecumênicas estão sendo violentamente tensionadas pela radicalização do fundamentalismo religioso que atenta contra o princípio jurídico da dignidade da pessoa humana pactuado em 1948 na Declaração Universal dos Direitos Humanos aprovada pelos países que derrotaram o nazifascismo da Alemanha, Itália e Japão. O fundamentalismo religioso parece ter recrudescido no Brasil, considerando o número de candidatos que se apresentaram ao processo eleitoral de 2018 buscando legitimar o voto do eleitor pela autodeclaração do candidato como liderança religiosa. O Tribunal Superior Eleitoral (TSE) registrou vários títulos religiosos como "nome de urna" de 568 candidatos. Reportagem do site de notícias UOL (PRAZERES, 2018) encontrou nos registros do TSE, 524 candidatos autointitulados pastor(a), irmão(ã), apóstolo(a), missionário(a); 24 candidaturas adotaram títulos de religiões afrobrasileiras como pai, mãe, Babalorixá. Vinte candidatos registraram-se como clérigos católicos, adotando o título de padre ou frei(ra).

A religião parece ter contribuído para acirrar uma disputa eleitoral já, por si mesma, polarizada. Poucos dias antes do primeiro turno, uma notícia internacional mostrava a recusa da comunidade científica internacional contra o fundamentalismo religioso, em um cenário religioso muito mais trágico e sangrento que o brasileiro. Denis Mukwege e Nadia Murad ganharam o Prêmio Nobel da Paz de 2018 "pelos seus esforços para pôr fim às violências sexuais nos 
Religare, ISSN: 19826605, v.15, n.1, agosto de 2018, p.127-155.

conflitos armados" provocados por extremistas religiosos na República Democrática do Congo e na Síria (PRÊMIO, 2018).

Com base na argumentação construída ao longo do artigo, parece plausível formular algumas respostas para as três perguntas formuladas na introdução. Como o Ensino Religioso contribui para a distinção republicana entre o dever da família e o dever do estado com a educação, especificamente, no campo do conhecimento religioso? A contribuição específica do Ensino Religioso parece ser o conhecimento científico acerca da distinção e, ao mesmo tempo, relação entre a educação privada propiciada pela família e a educação pública propiciada pelo Estado. Ou nas palavras de Cury, retomando os conceitos do primeiro artigo da LDB, diferenciando entre a educação família como sendo "educação lato sensu" e, "de modo bastante abrangente, e a educação escolar (stricto sensu) em instituições próprias" (2018, p. 316).

Quais seriam as implicações didáticas da disciplina Ensino Religioso que se inspiram na liberdade e na solidariedade? As experiências narradas pelo docente de Ensino Religioso parecem justificar a suspeita de que um bom recurso didático disponível para esta disciplina é o estímulo ao diálogo entre os alunos envolvendo as suas famílias em relação ao convívio religioso que realizam na sociedade. Apesar da polarização religiosa que parece predominar na atual conjuntura política brasileira, os relatos apresentados apontam para possibilidades de um convívio social capaz de valorizar a liberdade e a solidariedade entre distintas experiências religiosas, especialmente, quando partem de experiências concretas vivenciadas pelos estudantes e/ou suas famílias.

Como o Ensino Religioso pode e deve contribuir para a plenitude da personalidade, para o exercício democrático e para o trabalho? Para o desenvolvimento da personalidade basta lembrar os clássicos estudos construtivistas sobre a formação moral em Durkheim e Piaget, pouco explorados na produção analítica sobre as políticas educacionais. Para o exercício democrático, as contribuiçõos do ensino religioso apontam para o 
Religare, ISSN: 19826605, v.15, n.1, agosto de 2018, p.127-155.

desenvolvimento do apreço pela tolerância nos alunos e nas suas famílias. A contribuição do Ensino Religioso para o trabalho parece necessitar de uma précondição, qual seja, a própria formação para o trabalho com a disciplina ainda é uma questão não resolvida.

\section{Referências}

AMARAL, Daniela Patti do; OLIVEIRA, Renato José de; SOUZA, Evelin Christine Fonseca de. Argumentos para a formação do professor de ensino religioso no projeto pedagógico do curso de Ciências das Religiões da UFPB: que docente se pretende formar? Revista Brasileira de Estudos Pedagógicos, Brasília, v. 98, n. 249, p. 270-292, maio/ago. 2017. Disponível em: http://rbep.inep.gov.br/index.php/rbep/article/view/2628/pdf, acesso e, 13/10/2018.

BRASIL. Constituição da República Federativa do Brasil de 1988. Disponível em: http://www.planalto.gov.br/ccivil_03/Constituicao/Constituicao.htm, acesso em 10/09/2018.

BRASIL. Lei nº 9.394, de 20 de dezembro de 1996. Estabelece as diretrizes e bases da educação nacional. Disponível em: http://www.planalto.gov.br/ccivil_03/Leis/L9394.htm, acesso em 10/09/2018.

BRASIL. Lei no 9.475, de 22 de julho de 1997. Dá nova redação ao art. 33 da Lei nº 9.394, de 20 de dezembro de 1996, que estabelece as diretrizes e bases da educação nacional. Disponível em: http://www.planalto.gov.br/ccivil_03/Leis/L9475.htm, acesso em 15/10/2018.

BRIGHOUSE, Harry. Sobre Educação. São Paulo: Editora Unesp, 2011.

CNE/CP. Conselho Nacional de Educação. Conselho Pleno. Parecer $n^{\circ}$ CP 097/99. Relatora Conselheira: Eunice R. Durham. Formação de professores para o Ensino Religioso nas escolas públicas de ensino fundamental. Aprovado em: 06/04/99. Disponível em: http://portal.mec.gov.br/cne/arquivos/pdf/pcp097_99.pdf, acesso em 15/10/2018.

CURY, Carlos Roberto Jamil. A formação de professores e laicidade no ensino superior. Revista de Educação Pública, Cuiabá/MT, v. 27, n. 65/1, p. 311-327, maio/ago. 2018. Disponível em: http://periodicoscientificos.ufmt.br/ojs/index.php/educacaopublica/article/down load/6581/4266, acesso em 10/09/2018

DINIZ, Debora; LIONLO, Tatiana; CARRIÃO, Vanessa. Laicidade e ensino religioso no Brasil. Brasília: UNESCO; LetrasLivres; EdUnB, 2010.

LOREA, Roberto Arriada. O assédio religioso. In: __ et. al. Em defesa das liberdades laicas. Porto Alegre: Livraria do Advogado Editora, 2008. p. 159-172.

OLIVEIRA, Lilian Blanck de; $\mathrm{KOCH}$, Simone Riske. Diversidade cultural religiosa e formação de docentes de ensino religioso na FURB/ SC: tecendo 
cartografias. Numen: revista de estudos e pesquisa da religião, Juiz de Fora/MG, v. 15, n. 2, p. 457-481. 2012. Disponível em: https://numen.ufjf.emnuvens.com.br/numen/article/download/1815/1455, acesso em 10/09/2018.

OLIVEIRA, Tania Alice. A influência das políticas públicas na formação do professor brasileiro e sua relação com o Ensino Religioso. Revista Pedagógica, Chapecó/SC, v. 20, n. 44, p. 66-86, mai./ago 2018. Disponível em: http://dx.doi.org/10.22196/rp.v20i44.4455, acesso em 10/09/2018.

PRAZERES, Leandro. Evangélicos puxam alta de $11 \%$ do número de candidaturas com nome religioso Leandro Prazeres. UOL, Brasília, 25/08/2018.

Disponível

em:

https://noticias.uol.com.br/politica/eleicoes/2018/noticias/2018/08/25/candidatur as-de-religiosos-crescem-11-em-2018-evangelicos-lideram-ranking.htm

PRÊMIO Nobel da Paz contra o estupro como arma de guerra. Entrevista com Denis Mukwege e Nadia Murad. Revista IHU on-line, São Leopoldo, 06 Outubro 2018. Disponível em: http://www.ihu.unisinos.br/583473-premio-nobel-da-pazcontra-o-estupro-como-arma-de-guerra-entrevista-com-denis-mukwege-enadia-murad.

RODRIGUES, Edile Maria Fracaro; PEROBELLI, Rachel de Morais Borges; JUNQUEIRA, Sérgio Rogério Azevedo. O caráter pedagógico e epistemológico do Ensino Religioso. Religare, João Pessoa/PB, v. 8, n. 2, p. 181-192, out. 2011. Disponível em: http://www.periodicos.ufpb.br/ojs/index.php/religare/article/download/12500/7 248, acesso em 15/09/2018.

RUEDELL, Pedro. Educação religiosa: fundamentação antropológico-cultural da religião segundo Paul Tillich. São Paulo: Paulinas, 2007.

WEBER, Max. Ciência como vocação. In: . Ensaios de sociologia. 3. ed. Rio de Janeiro: Zahar Editores, 1974. p. 194-183. 